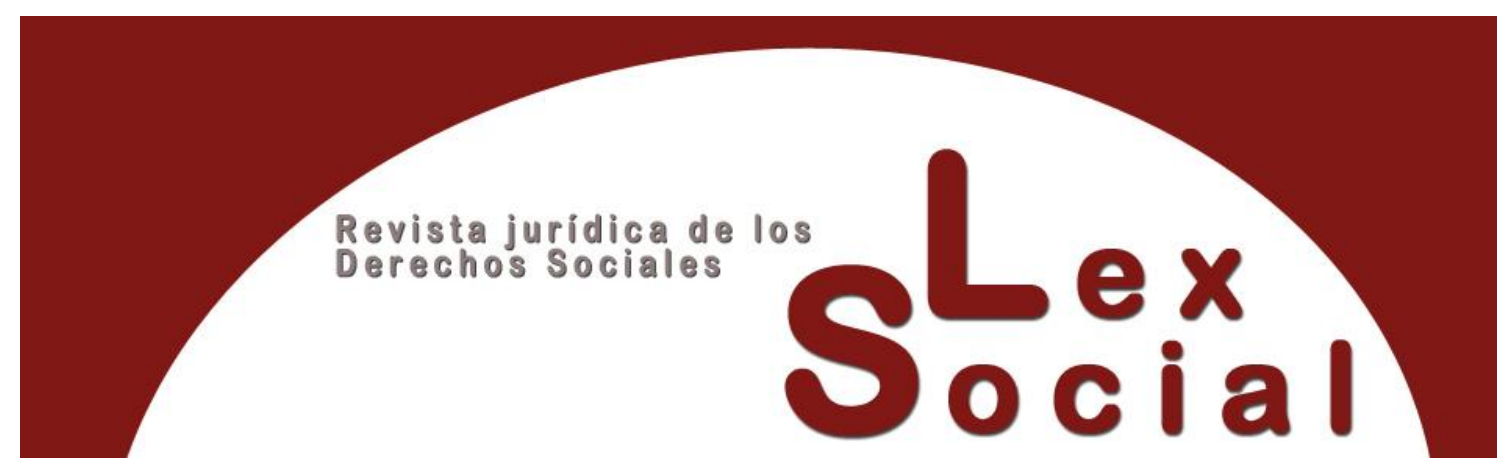

\title{
A CRITICAL ANALYSIS OF THE JOB INSTABILITY IN PLATFORM ECONOMY
}

\section{UN ANÁLISIS CRÍTICO DE LA INESTABILIDAD LABORAL EN LA ECONOMÍA DE PLATAFORMAS}

\author{
ROCÍO GALLEGO LOSADA \\ Associate Professor. Universidad Rey Juan Carlos \\ https://orcid.org/0000-0003-2470-6860
}

Cómo citar este trabajo: Gallego Losada, R. (2021). A critical analysis of the job instability in platform economy. Lex Social, Revista De Derechos Sociales, 11 (2), 122-144. https://doi.org/10.46661/lexsocial.6045

\begin{abstract}
This article reflects on the vulnerability of the new digital platform workers regarding their social rights, a highly controversial issue at the doctrinal and jurisprudential levels. Firstly, we analyse the greater job instability and lack of protection experienced by the workers in this type of platforms, and the labour legal framework that derives from these new business models. In this sense, the current doctrine can be grouped into two positions: a first one which defends that these workers should be considered employees and, therefore, remain under the umbrella of the general labour legislation; and a second one, that proposes a legal transformation to include these special workers. Secondly, we analyse the effects derived from the growing development of the platform economy for the Spanish Social Security system. This analysis focuses both on the effects of the protective action of the welfare state for their workers, as well as on its impact on the financing of the public pension system. The article draws a series of final conclusions warning about the possible crash of the fundamental social rights of platform workers.
\end{abstract}


KEYWORDS: platform economy, social rights, bogus self-employment, public pensions.

\section{RESUMEN}

En este artículo se reflexiona sobre la vulnerabilidad de los trabajadores de las nuevas empresas de plataformas digitales respecto a sus derechos sociales, una cuestión muy controvertida a nivel doctrinal y jurisprudencial. En primer lugar, se analiza la mayor precarización y desprotección del trabajador de este tipo de plataformas y el marco jurídico laboral que se deriva de estos nuevos modelos de negocios. En este sentido, la doctrina actual se agrupa en dos posturas, una primera que defiende que todos estos trabajadores se deben considerar trabajadores por cuenta ajena y deben permanecer bajo el paraguas de la legislación laboral general, y una segunda postura que propone una transformación legal para encajar a estos trabajadores especiales. En segundo lugar, se analizan los efectos que se derivan del desarrollo creciente de la economía de plataformas para el sistema de la Seguridad Social española. El análisis se centra tanto en los efectos de la acción protectora del estado de bienestar para estos trabajadores, como en lo referente a su impacto sobre la financiación de sistema de pensiones público. Se cierra el artículo con una serie de reflexiones finales en torno a la posible quiebra de los derechos sociales fundamentales de los trabajadores de plataformas.

Palabras Clave: economía de plataformas, derechos sociales, falso autónomo, pensiones públicas.

\section{SUMMARY}

\section{Introduction}

II. Precarious employment in the platform economy

1. Self-employed versus Employed workers

2. False autonomous workers versus social vulnerability. Insufficient regulatory framework?

III. Platform economy workers and Social Security

1. The difficult access to a public and decent pension of platform economy workers

2. Analysis of the impact of platform workers on the financial base of Social Security IV. Conclusions

Bibliography

Anexo 
Quote: "People do not know how to imagine the future and tend to repeat the past when they try to do it"

EDUARDO PUNSET

\section{Introduction}

The globalization and digitization have led to a new economic sector which is often called "sharing economy" . This sector takes advantage of the opportunities that internet offers to producers and consumers to carry out new collaborative activities. The sharing economy has many advantages. Digital platforms contribute to a more efficient use of resources, expand the supply of new products and reduce their price, thus obtaining general advantages for the entire economy generating a greater growth, improving competitiveness and innovation, and meaning an incentive for job creation. Final consumers can access a wider range of products and compare their price and quality, as well as share their positive or negative experiences of the goods and services consumed with many consumers.

However, the sharing economy is also the object of much criticism. On the one hand, the rapid growth of platforms and business activities around the sharing economy has increased the freedom to develop these initiatives without being severely constrained by norms or rules. However, this lack of regulation may cause negative situations such as the possible existence of unfair competition, a lack of protection of the final consumer through quality guarantees, the possible creation of monopolies that control entire markets and huge databases, and personal data protection problems.

In addition, a large part of the development of these new business activities is not truly based on a collaboration between producers and consumers, but is generated by companies that have taken advantage of new technologies through digital platforms to develop a new type of business. These firms are part of the so-called "platform economy", which refers to economic activities carried out through the use of online platforms. This way of delivering goods and services has given birth to different brand-new situations.

Platforms allow workers to offer their services to different companies. This includes clearly despair situations, ranged from highly qualified professionals, who work as freelance for several companies, organizing their time and developing skills that allow them to be part of different work teams; to low-skilled, low income and underemployed workers, who survive from precarious and poorly paid jobs which undermine their workers' rights and even eliminate their paid vacations.

From a business point of view, several recently created companies, such as Uber (urban transportation of people), Glovo or Deliveroo (urban prepared food delivery), or

\footnotetext{
${ }^{1}$ For a detailed description of the different types of sharing economy, see GIL, Javier, "¿Qué son las economías colaborativas?" [What are the sharing economies?], Revista Papeles de Relaciones Ecosociales y Cambio Global, $\mathrm{n}^{\circ}$ 141, spring 2018, pp. 49-62, in: https://www.fuhem.es/media/cdv/file/biblioteca/revista_papeles/141/Que-son-las-economiascolaborativas-JGil.pdf.
} 
BlablaCar, are currently using this kind of "external" workers in their production processes.

Simultaneously, another type of economy is also becoming more widespread among highly specialized companies looking for very qualified workers for specific projects limited in time. In the current macroeconomic context, more and more firms are trying to save costs hiring freelance workers for specific projects or tasks. Beyond the contractual relationship, it is increasingly common to work for different companies in a short period of time, with all the implications that this entails. This also poses a challenge for the labour factor, as it is hired to perform a specific job. The unions claim that this is an opaque work model, which leads to a high job insecurity, and which seeks to transform the labour market replacing employed workers with self-employed workers. In short, that model violates the usual labour relations.

Another difficulty that arises is the speed of the appearance and disappearance of these new business models that operate in the digital field, which can greatly complicate the work structure that is currently implemented. Furthermore, the conditions that they establish in the service contracts with their workers, in matters such as flexibility and availability, are changing so rapidly that labour laws cannot follow them. Spain is the second EU country, after Portugal, with the highest number of workers in the platform economy, with $15.1 \%$ of workers in this type of sector ${ }^{2}$. The characteristics of the Spanish productive structure, with a high presence of small companies, are also very relevant, since they condition the low quality occupations they perform.

How does all this fit into the current pension system? There are few studies that analyse the effects derived from the growing development of the platform economy for the Spanish Social Security system, both in terms of its impact on its financing and of the protective action of the welfare status for the workers ${ }^{3}$. One of the main problems faced by the Social Security system is that it was conceived and developed in the middle of the 20th century, when Western societies faced the massive incorporation of manual workers into their productive systems after the II World War. In spite of a certain delay due to the isolation caused by the Franco dictatorship, a similar model was implemented in Spain. Therefore, the current system of financing of Social Security in Spain obtains most of its economic resources from social contributions paid by participants in the labour market.

As the forms of work are evolving, it is currently convenient to propose measures in favour of a broader and more homogeneous workers' protection that integrates the new atypical forms of work that have appeared due to the digital transformation. In this sense, any dysfunction or abnormality that affects the behaviour of this labour market will have

\footnotetext{
${ }^{2}$ PESOLE, Annarosa, BRANCATI, Cesira Urzi., FERNÁNDEZ-MACÍAS, Enrique, BIAGI, Federico, GONZALEZ VAZQUEZ, Ignacio, Platform workers in Europe, Luxembourg: Publications Office of the European Union, 2018, p. 15.

${ }^{3}$ SANCHEZ CORUJO, Borja, "La gran transición: la economía de plataformas digitales y su proyección en el ámbito laboral y de la Seguridad Social" [The great transition: the economy of digital platforms and its projection in the workplace and Social Security], Temas Laborales, $\mathrm{n}^{\circ}$ 141/2018, pp. 37-66; CERIC, The Social Protection of workers in the Platform Economy, European Commission, IP/A/EMPL/2016-11, November 2017.
} 
a significant impact on the volume of financial resources available to guarantee the social benefits provided by the Social Security system, and it will reduce the amount of future pensions of today's contributors.

This article studies this problem, dealing with two aspects. The first part is an introduction about the general situation of precariousness of the workers of "platform companies". Then, the second part deals with the influence of this precariousness in the Social Security system, considering two different facts: the difficulties that these workers will have to achieve a sufficient pension when they retire, and the impact of the generalization of the platform economy for the global financing of the Social Security. Finally, our conclusions offer different possible solutions to these problems.

\section{Precarious employment in the platform economy}

The digitization of the economy has allowed the emergence of numerous platforms that, through the use of internet and mobile phones, manage to match jobs and services' supply and demand very quickly. The speed with which job opportunities are offered and accepted and the easy access to platforms and applications ("apps") allow the companies to get in contact with a large number of people available to complete tasks or actions at a specific time.

Platform companies face certain challenges and needs but can profit from some opportunities as well. Amongst the former, these firms have to restructure their managerial and organizational practices to face the challenges of globalization. They must also face different and numerous regulatory gaps and changes. The increase in the competition requires them a greater flexibility of their workers. At the same time, they get some advantages from the absence of a physical proximity between employer and employee, which allows the remote provision of services and evaluation of the job ${ }^{4}$.

Platform companies have chosen to increase the weight of "atypical" work relationships based on hiring self-employed workers ("non-standard employment"), compared to the "classic" or "typical" relationship associated with employed workers with a stable contract $^{5}$. Atypical work is gaining weight in the job market. A job is considered atypical when it has at least one of the following characteristics: self-employed workers, temporary contracts instead of indefinite duration, part-time jobs, absence of reciprocity, bilateral legal relationship, and economic subordination ${ }^{6}$. In this sense, platform workers have become the most "atypical" ones, since they combine all the previous characteristics.

\footnotetext{
${ }^{4}$ ILO, Non-standard employment around the world: Understanding challenges, shaping prospects (Full report in English and summary in Spanish entitled "El empleo atípico en el mundo: retos y perspectivas"), 2016, Geneve.

${ }^{5}$ For a detailed analysis on this issue, see SPASOVA, Slavina, BOUGET, Denis, GHAILANI, Dalila and VANHERCKE, Bart, Access to social protection for people working on non-standard contracts and as self-employed in Europe. A study of national policies, European Social Policy Network (ESPN), European Commission, Brussels, 2017.

${ }^{6}$ SCHOUKENS, Paul and BARRIO, Alberto, "The changing concept of work: When does typical work become atypical?", European Labour Law Journal, 8(4), 2017, pp. 306-332.
} 


\section{Self-employed versus Employed workers}

Many companies establish an employment relationship with their workers that can be described as typical or classic, having the following characteristics: many workers have an permanent full-time contract, although they can perform their activity along with workers who have other types of contracts (temporary or part-time); the work is carried out in the offices of the company, which provides its workers with the materials and services necessary to carry out their job; the workers are integrated into the hierarchical structure of the company, where they receive instructions about the type of work to be carried out, the working time, the working conditions, etc.; in exchange for their work in the company, the workers receive a salary that includes contributions along with other labour rights such as paid vacations, sick leave, or protective legislation on the minimum wage or against discrimination.

Labour legislation has established appropriate contracts for this situation. Thus, the most common contract is the permanent or indefinite one, which is agreed without establishing limits as to its duration, so it remains in force until the company or the worker breaks it. In the event that the company dismisses the worker, it must pay him a higher severance pay than in other types of temporary contracts. The permanent contract can be signed as a full-time one, a part-time one, or for the provision of discontinuous services. In Spain, around $75 \%$ of workers ( 3 out of 4 ) have this type of contract. The National Institute of Statistics (INE) has obtained this data from its quarterly labour survey, the Labour Force Survey or EPA ${ }^{7}$. In the latest data, the EPA for the fourth quarter of 2020, the percentage of workers with an indefinite-term contract reached a $75.4 \%$ of the total number of workers, which rises slightly for men to $77.2 \%$ and decreases for women to $73.4 \%$.

In the temporary contract ${ }^{8}$, the relationship between the employer and the worker is established for a specified period of time, and the contract can be full or part-time. Although these contracts are designed for certain temporary jobs, quite common in Spain due to the strong development of seasonal industries such as tourism, in many cases these

\footnotetext{
${ }^{7}$ In addition to the EPA, there are two other sources of data on the type of contract in Spain. One is offered by the Public State Employment Service (SEPE) of the Ministry of Labor, Migration and Social Security, which publishes each month the number of contracts registered in the Public Employment Offices and Social Security affiliation, distinguishing between the type of contract. Their data shows that only $10 \%$ of the registered contracts are indefinite, but it is an equivocal fact, because by the very definition of the contracts, an indefinite contract does not have to be registered, since it is in force indefinitely, while nonindefinite contracts are registered each time they are formalized. For example, a company with 100 workers that has 75 with an indefinite contract (the average for Spain), assuming that these 75 contracts are formalized at the beginning of the year (it does not have to be this way, they can be formalized even in previous years, and not would appear in the statistics), if the rest of the 25 workers sign a contract each month, at the end of the year 300 non-indefinite contracts ( $25 \times 12)$ and only 75 indefinite contracts would have been signed in that company, that is, $80 \%$ of the contracts would be non-indefinite and only $20 \%$ indefinite, which does not reflect the real situation of the company.

${ }^{8}$ The Spanish labor law requires that temporary contracts must be transformed into permanent ones, when there are procedural errors (not registering the worker in the Social Security system, not leaving the contract in writing, or if the worker continues working after the date of expiration of the temporary contract), when the worker has been hired for 30 months with one or more temporary contracts and more than 24 months in the same company, when there is no temporary cause assigned to the job, when the worker exceeds his maximum working time or performs tasks not stipulated in the temporary contract, that is, if there is a fraud of law because the company uses a temporary contract when the nature of the contract is indefinite.
} 
contracts are used in jobs of indefinite duration, due to the fact that they have lower termination costs. Spanish legislation provides also with two other specific contracts for training and internships for new workers, the training and apprenticeship contract and the internship contract.

In Spain, there are numerous kinds of entrepreneurs, which are actually based on the legal form of each company (joint-stock company, limited liability company, cooperative, etc.). One of these legal forms is that of an individual entrepreneur, which is a natural person who performs on her/his own account a specific economic activity, for example, setting up a clothing store, a bakery or a small legal consultancy. The individual entrepreneur has advantages and disadvantages compared to other types of companies. The advantages are the greater simplification in numerous procedures (registration, dissolution, filing of taxes...), lower maintenance costs and total control of the company by a single partner. The main disadvantage is that the s/he is personally liable with her/his present and future assets, including those belonging to the spouse/husband in a marriage community property regime ${ }^{9}$, in addition to the fact that the tax burden from certain benefits (around 45,000 euros) is greater than in the case of other companies. For this reason, the figure of the individual entrepreneur is commonly used for very small companies that have just started, but as soon as they obtain a larger size or require the contribution of new partners, it is usually transformed into another type of company.

We should not confuse an individual entrepreneur with a self-employed worker. An individual entrepreneur must register in the Social Security system and must join a specific scheme created for Self-Employed Workers. Therefore, all individual entrepreneurs are self-employed workers.

But the reverse is not true, as not all self-employed workers are individual entrepreneurs. In Spain, the figure of the self-employed worker is regulated by the Law 20/2007 of the Statute of Self-Employed Work, of July 11, 2007. As established in article 1 of that Law, self-employed workers are natural persons who regularly, personally, directly, on their own account and outside the scope of management and organization of another person, carry out an economic or professional activity for profit, whether or not they give employment to workers" (translated from the Law).

So, there are two kinds of self-employed workers. Firstly, there are individual entrepreneurs who create a company to which they personally dedicate part of their time and effort. But along with them, there are other self-employed workers who do not have a company (and so, they are not individual entrepreneurs) and are engaged in performing tasks demanded by one or different companies. The distinction between the selfemployed workers who own a company and those who don't is relevant, because the latter figure is closer to employees. The difficult legal distinction between employees and selfemployed workers without a company is the origin of the workers' rights problems in the platform economy.

\footnotetext{
${ }^{9}$ In Spain, the matrimonial regime can choose between a property separation regime (the money and assets earned and the debts contracted by each member of the marriage are separated) and a community property regime (the income and debts are distributed equitably between the two members of the marriage).
} 
The problem arises because companies could try to replace, in certain tasks, employees with self-employed workers, in order to make their production more flexible and save the costs of social contributions, which are paid by the self-employed workers themselves ${ }^{10}$. In order to prevent this situation, the Law 20/2007 (article 11) introduces the figure of the economically dependent self-employed worker (TRADE), who is a self-employed worker with a strong and almost exclusive economic dependence on a single client which takes place when, at least, a 75 percent of the worker's income comes from that client. This is, therefore, the legal figure of the self-employed worker closest to the employed person, for which the law establishes very restrictive conditions that define with objective criteria the cases in which the activity is carried out outside the scope of organization and management of the client who hires that self-employed person:

- The TRADE cannot be in charge of employees ( $\mathrm{s} / \mathrm{he}$ can have one in certain circumstances such as risk of pregnancy or care of young children or dependent or disabled relatives in her/his charge).

- The TRADE cannot carry out her/his activity in an undifferentiated way with other workers of the client

- The TRADE must have her/his own productive infrastructure and materials independent of those of her/his client

- The TRADE must have her/his own organizational criteria

- The TRADE must charge the client firm fees based on the result of her/his activity, assuming a risk.

In addition, the law expressly prohibits to use this figure in case of owners of shops, industries, businesses and offices open to the public, and professionals who exercise their profession jointly with others in a corporate regime or under any other legal form admitted by the Law.

The objective of these strict conditions for the economically dependent self-employed worker (TRADE), as recognized in Preamble III of Law 20/2017, is to "prevent the possible misuse of this figure, given that we are moving along a border that is not always precise between self-employed workers, economically dependent self-employed workers and employees". Therefore, the "classic self-employed worker" mentioned by the law is the one who runs her/his own company, although s/he can also be a professional whose services are demanded by various companies. This Law pointedly delimits the intermediate figure of the TRADE, a self-employed worker who performs very similar tasks to that of an employee for a single company. In the first place, by establishing the criterion that at least $75 \%$ of the worker's income has to come from a single client, thereby

\footnotetext{
${ }^{10}$ Without going any further, an example of the perverse use of the self-employed worker can be found in the Spanish public universities, with the figure of the 'profesor asociado'. This figure is designed so that private sector professionals can teach in the university to transmit the vision of private business in the university, but on many occasions this figure is used as a way of hiring workers who want to be full-time professors at the university, whose contract is much more flexible and cheaper for the university by forcing them to register as self-employed workers.
} 
differentiating this figure from that of the classic self-employed person who distributes her/his work among several companies. And, secondly, establishing quite restrictive and relatively specific criteria to try to objectively delimit that the activity of the selfemployed worker is carried out outside the scope of organization and management of the company that hires that person.

\section{False autonomous versus social vulnerability. Insufficient regulatory framework?}

Two positions predominate in the doctrine to address the problem of providing an adequate legal framework for workers in the platform economy. According to the first one, all these workers should be considered employees and should remain under the umbrella of general labour legislation. The second position proposes to transform the legislation to adapt it to these special workers ${ }^{11}$.

The first position uses the following arguments against establishing a special employment relationship different from traditional self-employment in the platform economy. The common labour legislation is flexible enough to allow regulatory adaptations based on certain specific organizational models (for example, joint work, remote work, shift work or night work). In addition, labour evolution can make digital and less digital workers coexist within the same company. In a very short time, the Covid-19 pandemic has made many workers, who were employed in traditional jobs (developed personally in an office with a specific schedule) develop their work remotely, with the changes that this has caused in terms of time flexibility or control through computer applications. Therefore, it cannot be ignored that some of the forms of work that were initially used only by platform companies are becoming more widespread in other traditional firms.

The fear that the authors linked with this first position declare about the configuration of a special employment relationship is that it could erode some aspect of the protective status of the service providers, deepening into the so-called "uberization" of the economy, that is, the loss of labour rights for these workers.

These authors state that the legal framework of the European Union only recognizes two possible categories of service providers, the employee and the self-employed worker. So, the creation of intermediate figures could be troublesome. In fact, that intermediate status currently exists in Spain, the TRADE, being the one normally used by platform companies, although it belongs to the scope of the Statute of Self-Employed Work.

Finally, a last argument to defend this position, especially developed in the United States, maintains that Labour Law must always protect the weakest party, including those selfemployed workers in a social and economic situation very similar to dependent workers, although their legal characteristics are not similar to those of these workers, to compensate for the imbalance of the bargaining power of the parties.

\footnotetext{
${ }^{11}$ For a list of authors in both positions, see PRIETO PADIN. Patricia, "La calificación jurídica de TRADE en la prestación de servicios a través de las plataformas digitales delivery: una solución contractual y judicial en entredicho" [The legal qualification of TRADE in the provision of services through delivery digital platforms: a contractual and judicial solution in question], Revista General de Derecho del Trabajo y de la Seguridad Social, $\mathrm{n}^{\circ}$ 56, 2020.
} 
The second position proposes the creation of a special labour regulation for workers in platform companies. The basic idea of these authors is that the workers of the platform companies do not fit into the working conditions that the legislation establishes for employees. The fundamental characteristics that differentiate these platform workers from traditional employees are, firstly, the flexible hours, which allow these workers to choose when to work and to refuse certain services. This faculty is very strange in traditional workers, at the same time it is incompatible with the labour regulations on fixed salary measured by work hours, schedules, breaks and vacations. Including these workers in the general labour legislation (the Workers' Statute) is complicated even using the special regulations permitted by the law, like job notice boards or preference rights to work.

Secondly, collective bargaining is also difficult to develop in platform companies. It is very difficult to count the number of workers and their workload in this sector, since a person can work for several platforms and contact between workers is less frequent, hindering the election of representatives.

Finally, an element that is also special in this type of work is the ownership of the means of production, such as bicycles, mobile phones, cars, etc. In traditional work, the employer must compensate the worker for all the expenses incurred in their provision of services, something that, in in case of platform work, with great freedom of workers to choose their working days and work for several companies, would be difficult to regulate with current legislation. The business organization of the new technology companies has changed the classic legal signs of employment, so these classic signs must be replaced by new ones derived from the digitization of the economy ${ }^{12}$.

This special regulation would mean creating a new special employment relationship, something contemplated in the Workers' Statute (article 2), which would have to accomplish some features ${ }^{13}$. First of all, it could only be used by companies in which all the workers are eligible to benefit from this special regime. If normal employees coexist with these platform workers in a company, the introduction of this special regime could end up affecting all the workers, leading to an "uberization" of the economy and the companies ${ }^{14}$. Secondly, platform workers must maintain their relative independence and freedom to choose work hours, including the ability to work for multiple platforms.

\footnotetext{
${ }^{12}$ TODOLÍ-SIGNES, Adrián, El trabajo en la era de la economía colaborativa [Work in the collaborative economy era], Tirant lo Blanch, 2017, exposes 18 of these new signs. A summary of these signs can be seen in TODOLÍ-SIGNES, Adrián, "Nuevos indicios de laboralidad en la economía de plataformas virtuales (Gig economy)" [New signs of employment in the virtual platform economy (Gig economy)], Papeles de relaciones ecosociales y cambio global, $\mathrm{n}^{\circ}$ 140, 2017/18, pp. 99-100.

${ }^{13}$ TODOLÍ-SIGNES, Adrián, "The impact of the 'Uber Economy' in labor relations: the effects of virtual platforms in the employment contract" [The impact of the 'Uber Economy' in labor relations: the effects of virtual platforms in the employment contract], IUS Labor, 3/2015, December 2015, pp. 21-24, in: https://ssrn.com/abstract=2705538. This author qualifies these workers as "quasi-independent" (p. 19).

${ }^{14}$ We refer to workers who perform the same job, for example, in food delivery companies, to all riders of that company. If the company also has other workers doing other administrative or computer tasks, that group of workers could continue under a normal regime of employed workers, while the riders could be in a different special regime. But there could not be, within a company, a group of riders with a standard contract and another group with the special regime.
} 
In our opinion, the introduction of a special labour regulation for workers in platform companies is the most suitable solution. The relativity of these measures refers to the fact that companies can establish the minimum instructions necessary for the proper functioning of the service, while leaving ample freedom to the workers. It should not be forgotten that, if platform companies are forced to hire their workers as employees, the workers could lose a large part of that freedom (despite obtaining other benefits), and many of them, due to their own lifestyle (students, housewives, etc.), appreciate critically this freedom, and therefore it is not convenient for them to work as totally dependent employees under the orders of the company. Nevertheless, the proposal of a special regime for platform workers must include other protection elements such as the minimum wage, liability for damages of the workers, or compensation for the expenses incurred by the worker when rendering their service, although it is possible to maintain the concept that the ownership of the means of development of the service (transport, communication elements, etc.) belong to the worker himself.

There is currently a controversial on the working patterns of employees hired as selfemployed by platforms that is having a very intense development in courts. Since 2018, the Spanish courts, specifically the Social Courts, have issued numerous judgments regarding the employment situation of workers in food delivery companies. The last of these judgments has been issued by the Spanish Supreme Court in plenary session after an appeal for the unification of the case-law ${ }^{15}$. Although the judgments have been contradictory, most of them have opted to recognize the labour nature of the contractual relationship, a doctrine that has already been consolidated as a judicial doctrine by the Plenary of the Social Chambers of the Superior Courts of Justice of Madrid, Catalonia and Castilla y León, and finally by the Spanish Supreme Court.

Based on the previous court decisions, a new law (known as Rider Law) has been approved to regulate the labour rights of digital platforms' delivery workers "Real Decreto-ley 9/2021, de 11 de mayo, por el que se modifica el texto refundido de la Ley del Estatuto de los Trabajadores, aprobado por el Real Decreto Legislativo 2/2015, de 23 de octubre" [Royal Decree-Law 9/2021, of May 11, which modifies the revised text of the Workers' Statute Law, approved by Legislative Royal Decree 2/2015, October 23]. The initial bill was very ambitious, as can be seen from its very illustrative title: "Anteproyecto de ley contra la huida del derecho del trabajo a través de las nuevas

\footnotetext{
15 Judgment of the Spanish Supreme Court 805/2020, of September 25 (RJ 2020, 5169). Appeal for the unification of doctrine 4746/2019. Speaker: Excmo. Mr. Juan Molins García- Atance. An analysis of this sentence can be seen in BARCELÓ FERNÁNDEZ Jesús, "Cerco a los falsos autónomos en las plataformas digitales" [Siege of false self-employed on digital platforms]", Revista General de Derecho del Trabajo y de la Seguridad Social, no 57, 2020; ROJO TORRECILLA, Eduardo, "Pues sí, la saga Glovo (y los glovers) merecen un caso práctico. Notas a la sentencia del TS de 25 de septiembre de 2020, que declara la laboralidad, y recordatorio de las sentencias del JS núm. 39 de Madrid de 3 de septiembre de 2018 y del TSJ de Madrid de 19 de septiembre de 2019 (y II)" [Well, yes, the Glovo saga (and the glovers) deserve a case practical. Notes to the judgment of the Supreme Court of September 25, 2020, which declares employment, and reminder of the judgments of JS n 39 of Madrid of September 3, 2018 and of the Madrid Supreme Court of September 19, 2019 (and II)]", Blog of Eduardo Rojo Torrecilla (October 2, 2020), in: https://translate.google.com/translate?hl=es\&prev= t\&sl=es\&tl=en\&u=http://www.eduardorojotorrecilla. es/2020/10/pues-si-la-saga-glovo-y-los-glovers 2.html
} 
tecnologías [Draft law against the escape from labor law through new technologies]. But the negotiations amongst the Government, the social agents and the employers have largely decaffeinated the scope of the law, to the point of limiting it to the introduction of a new additional provision (23rd) in the Workers' Statute (RCL 2015, 1654). The draft of the provision indicates the following: "By application of the provisions of article 8.1, the activity of persons who provide paid services consisting of the distribution of any consumer product is presumed to be included in the scope of this law, by employers who exercise the business powers of organization, management and control indirectly or implicitly, through the algorithmic management of the service or working conditions, through a digital platform. This presumption does not affect the exclusions from employment provided for in article 1.3 of this regulation".

However, this legislative amendment does not entail an important change in the possible employment of platform workers. Firstly, this rule is very restrictive and only affects a very specific sector of the platform economy, that of delivery activities, leaving the rest of the sectors outside of its scope. Secondly, the most prominent legal element of this amendment is that it introduces a presumption of employment. But in the Workers' Statute there is already a general presumption of employment, while this particular presumption needs some specific conditions to be met: employers with entrepreneurial power, algorithmic management and digital platform. Therefore, it will be more comfortable to assume the general presumption that already existed and not to use this new one which requires more conditions. Finally, this new legislation does not mean an immediate and automatic transformation of platform self-employed workers into employees, since companies must do it voluntarily, and in case they refuse to, employees will have to require it at the courts. So, this new law does not add anything new, nor it is especially effective in defending the labour rights of platform workers. We will have to wait and see how events happen, as there is a period of 3 months to implement this legislation since it was published in the Official Gazette of the Spanish State on May 11, 2021 (Boletin Oficial del Estado BOE).

Probably, the companies affected (Glovo, Deliveroo and Uber Eats) will have to hire their delivery workers as employees, which will increase their costs. In fact, the legislative project includes an additional element: "A new section is introduced: d) Be informed by the company of the parameters, rules and instructions on which the algorithms or artificial intelligence systems that affect the decision making processes that can affect working conditions, access and maintenance of employment, including the creation of profiles". This element recognizes the right of the works councils, or any other forms of representation, to know not only if these algorithms exist, but on which parameters they are based. It is therefore a regulatory innovation to protect people involved in technological processes. Having transparent and ethical algorithms is essential not only for home delivery apps, but in any company. The challenges caused by the use of artificial intelligence systems in companies and in the workplace are not exclusive to digital platforms. However, companies have complained about having to give their algorithms unions. 
Currently, there is no initiative to transform self-employed workers into employees in the rest of the sectors of the platform economy. Digital companies will continue to look for loopholes to try to have employees who are listed as freelance. For this reason, the Government could have opted for regulations of the digital economy including wider protections for self-employed workers, instead of forcing them to be transformed into employees. This has happened in many other European countries, reinforcing the basic principles of the European social model to try to put an end to the vulnerability faced by workers in this sector ${ }^{16}$.

In any case, although platform workers are considered mostly as employed by the firms, these workers will continue to bear several risks of job insecurity and a difficult access to sufficient contributory pensions within Social Security. Moreover, these new forms of employment based on digital platforms will impact, as well, on the financing of the public pension system. The next section analyses these two issues.

\section{Platform economy workers and Social Security}

Although the group of platform economy workers is very heterogeneous, the majority of them are amongst the most affected by job instability and an important variability and uncertainty in their usual income. This means that these workers, despite having a job, may be in danger of poverty and social exclusion. Furthermore, it should not be forgotten that this vulnerability is associated with the instability of entrepreneurs in a sector based on new Internet companies with limited investments and a small business structure, whose survival over time is uncertain.

Job instability prevents workers from reaching an adequate level of protection, but also affects other areas of society. For instance, job instability could be linked with the collapse in the birth rate in Spain, necessary to maintain the financing of the public pension system. This system, whose main source of income comes from social contributions, needs a broad base of contributors compared to the number of pensioners. The low fertility rates, that barely exceed one child per woman of childbearing age, the high rates of youth unemployment, the high job instability and temporality for the population between 18 and 39 years of age, and a notable income inequality, are important threats to the sustainability of public pensions.

\section{The difficult access to a public and decent pension of platform economy workers}

The rise of the digital economy may cause an increase in the number of self-employed workers at the expense of employees. Most digital platform workers currently fall under the Special Regime for Self-Employed Workers (RETA), established in the Ley General de la Seguridad Social (LGSS) [General Social Security Law] ${ }^{17}$ (article 305.1 and article

\footnotetext{
${ }^{16}$ In France, which approved the regulation of messaging employees through Apps, renouncing their consideration as labour personnel, but demanding that companies recognize these self-employed, a series of rights like labour, (insurance, rest, etc.).

${ }^{17}$ Royal Legislative Decree 8/2015 of 23 October approving the consolidated text of the General Social Security Law.
} 
305.2, F) LGSS in the case of TRADE). This poses a serious problem of inadequate future benefits for these workers, which cannot reach an adequate and sufficient pension.

Due to the shyness of the legislative reform or Rider Law (Royal Decree-Law 9/2021), it still does not seem foreseeable that the obligation to establish an employment relationship will be extended to the majority of digital platform companies. However, even if this happened and all these workers were registered in the General Social Security system, regardless of the length of the working day, it is foreseeable that the majority of these workers will pay the interprofessional minimum contribution base ${ }^{18}$.

The Social Security contribution, the unemployment insurance, the Salary Guarantee Fund and the professional training derived from part-time work contracts are based on the remuneration received according to the number of hours worked every month. The minimum contribution bases applicable to workers with part-time contracts will be adjusted, so that the contribution in this type of contract will be equivalent to the full-time contribution for the same unit of time and similar remuneration.

The lower number of hours worked affects the salary of these workers, and it will also affect the amount of their future retirement pension, although it does not affect the requirements to get the pension. These requirements are having a minimum contribution period of 15 years, two of them included in the last 15 years before retirement. This period is calculated considering all the days worked, regardless of the number of hours worked in each day. This was established by the Resolution of the Spanish Constitutional Court $91 / 2019$, of July $3,2019^{19}$, which understood that the previous regulation of the calculation of the retirement pension in cases of contribution through part-time contracts was null, as it violated the principle of equality between full-time and part-time workers, and also for being discriminatory indirectly due to gender, given that part-time workers are mostly women.

Regardless of this last change, part-time workers have a lower pension than full-time employees, as both their salary and their contribution to Social Security is lower than the full-time worker's ones. The temporary nature of the contracts also plays against parttime workers. In addition, empirical evidence indicates that part-time workers usually have less training and experience, which leads to fewer opportunities in the labour market, affecting their professional career and their future pensions. All these reasons cause the

\footnotetext{
${ }^{18}$ The minimum contribution base is linked by law to the interprofessional minimum wage as a part-time worker. The part-time contract is defined as the contract agreed to perform work for a number of hours per day, week, month or year less than the full-time worker on a comparable full-time, or in its default, the full time provided for in the collective agreement.

${ }^{19}$ It is based on the judgment of May 9 of that same year of the Court of Justice of the European Union which stated that "the additional application of a partiality coefficient relative to part-time work goes beyond what is necessary to calculate the pension with the time quoted". Therefore, "represents, for the group of workers who provided their services on a reduced part-time basis, that is, less than two thirds of a comparable full-time job, a reduction in the amount of the retirement pension greater than the amount that would only result from taking into consideration their working hours", which caused an unjustified double penalty: on one hand, the contribution bases of the part-time workers are already lower than those of the full-time workers and, on the other hand, as a second penalty, the partiality coefficient reduced the calculation of the number of days contributed.
} 
difficulties these workers find to accumulate long periods of contribution in a contributory pension system like the Spanish one.

In another attempt to increase Social Security contributions, Law 27/2011 modified the Statute of the Self-Employed Worker, admitting the possibility of part-time work. Moreover, this possibility could have been a solution for low-income self-employed platform workers ${ }^{20}$. This regulation would make it possible to combine different schedules and, in addition, it would imply a reduction in costs, although there is an evident risk of labour fraud since a self-employed worker who works full-time could claim that s/he works part-time to pay less contributions to the Social Security. However, its planned entry into force in 2014 has been postponed by successive budget laws and it is not yet in force, so working as a part-time self-employed person with reductions in contributions is still a pending issue ${ }^{21}$. Even if a self-employed person actually works part-time, s/he will pay the fee as if s/he was working full-time.

An alternative for those who cannot complete a full day as a self-employed person is multi-activity, which allows self-employed workers to work at the same time as an employee. In this way, they can combine their work in the Self-Employed Regime and in the General Regime, contributing to the Social Security of both, having access to a lower contribution base or to a refund of contributions ${ }^{22}$. However, only those workers who register for the first time in the RETA can benefit from moonlighting ${ }^{23}$. It should not be forgotten, in addition, that the pension reform, which is being negotiated since 2020, proposes the eventual entry into force of a contribution system for the self-employed workers according to their real income, in order to give greater contributivity to the RETA model. The aim is to correct the current dysfunctions derived from the fact that self-

\footnotetext{
${ }^{20}$ GALA DURÁN, Carolina, "El impacto de la robotización y de las plataformas virtuales en los sistemas de seguridad social europeos, en particular el caso de España" [The impact of robotization and virtual platforms on European Social Security systems, in particular the case of Spain] in Digital Work and personal data protection: key issues for the labour of the 21st century, Newcastle, Cambridge Scholars Publishing, 2017, p. 59.

${ }^{21}$ The latest regulation on self-employment, once again postpones the obligation to develop this regulation that allowed part-time work in the Self-Employed Regime was "Real Decreto-ley 28/2018, de 28 de diciembre, para la revalorización de las pensiones públicas y otras medidas urgentes en materia social, laboral y de empleo". There is an exception in which the Administration allows the self-employed worker to benefit from partial paternity leave for eight weeks. Of course, they must be the four weeks immediately following the birth of the child, they must be uninterrupted and full-time. In that case, there is a $50 \%$ discount on the fee paid, which means that you are only entitled to $50 \%$ of the corresponding paternity benefit.

${ }^{22}$ In this case, the self-employed person pays the fees like any other. But the company that has him paid for part-time also does it. An excess contribution is generated, which is returned by Social Security annually. But the self-employed in multi activity overtakes it.

${ }^{23}$ The Entrepreneurs Law dictates that there is a bonus on these fees. The reduction that is applied on the minimum basis of the self-employed person is 50\% in the first 18 months after joining the RETA and 25\% from months 18 to 36 . If we focus on the self-employed worker who also dedicates your day to work parttime for a company, the reduction that is applied on the basis is less: up to $25 \%$ reduction in the minimum contribution base in the first 18 months and up to $15 \%$ reduction in the 18 months to 36 . We are talking, therefore, of a reduction in the monthly fee for 3 years. However, if workers choose this option, they cannot benefit from the flat rate for new self-employed workers.
} 
employed people can choose the level of their contributions to the public pension system while the employed workers cannot.

Does this new law solve the problem of financing and future benefits of riders' pensions? Of course it does not. Although it regulates an employment relationship between the company and the rider, it also implicitly defines the costs that the company is willing to bear for this service, which in most cases will lead them to receive the minimum wage. It is not clear that the "classic" formula of forcing platform workers to be framing as employees would improve their social protection of platform workers. It may be thought that the solution is to decouple the social protection of the type of employment that is carried out, so that both dependent or autonomous workers can enjoy identical social protection, walking towards a universal protection model that does not take into account employment and its variants to provide social protection to workers. Furthermore, a scheme in its basic principles is guaranteed equally for all workers.

\section{Analysis of the impact of platform workers on the financial base of Social Security}

The pension system in Spain is based on two main pillars, solidarity and contribution. Solidarity has been a principle that the Constitutional Court and the legislation have progressively consolidated as a cornerstone of the Social Security system, so that it can no longer be understood without a direct reference to interpersonal, interterritorial and intergenerational solidarity. This objective is aimed at establishing a poverty alleviation program through a guarantee of minimum pensions, which must be fully financed by taxes, producing a transfer of income from those who have the most to those who have the least, and must be directed to those who could not work, or could not work enough time, to enjoy a decent pension.

The principle of contributory proportionality of our public pension system indicates that there must be a close relationship between what is received during retirement and what was contributed to the public system during working life. In the "Informe de Evaluación y Reforma del Pacto de Toledo [Evaluation and Reform of the Toledo Pact Report]" approved by the Committee for the Follow-up and Evaluation of the Toledo Pact Agreements, in its session on October 27, 2020, and subsequently ratified in the Congress of Deputies on October 192020 , it is expressly mentioned that "the Commission confirms the need to preserve and reinforce the principle of contributivity, understood as the existence of a balanced relationship between the amount of the recognized benefit and the contribution effort previously made by each worker". In addition, in the Recommendation 5, this report also specifies that "the progressive extension from 15 to 25 years of the period of time used to calculate the regulatory base -which will culminate in 2022- implies a reinforcement of the contributivity of the tax system pensions", explicitly recognizing the number of years of contributions as the basis for calculating that pension ${ }^{24}$.

\footnotetext{
${ }^{24}$ A future extension of 25 to 35 years in the period to calculate the retirement is also on the table. The "Pacto de Toledo 2020" also recommends evaluating the possibility of "choosing the most favourable years in determining the regulatory base of the pension". This recommendation tries to prevent certain groups of
} 
The regulatory changes of the last years have reinforced both the principles of solidarity and contributivity. The principle of solidarity has been put into practice, for example, by raising the amount of minimum pensions and limiting the increase in maximum pensions. And the contributory principle has been approached from the contribution side by gradually increasing both the number of years used for the calculation of the pension regulatory base and the maximum contribution base ${ }^{25}$.

These changes can harm certain groups. Thus, the amount of benefits for workers in the digital economy can be particularly affected. Demanding long professional careers and years of contributions from temporary workers can lead, on one hand, to insufficient funding for the system as a whole and, on the other hand, to an insufficient amount of future contributory pension rights ${ }^{26}$. This could lead many of these workers to place themselves on the margins of the system, or close to the minimum pension or pensions supplemented by minimums ${ }^{27}$.

Another of the recent regulatory changes is the progressive increase of the retirement age, up to 67 years in 2027. The gradual application of this raise in the retirement age and the years of contributions is established in art. 4, 20th transitory provision of "Ley 27/2011, de 1 de Agosto, sobre actualización, adecuación y modernización del sistema de Seguridad Social". Raising the retirement age is one of the simplest measures to adjust the accounts of the public pension system. However, the prolongation of the working life in older workers may have a negative impact on young workers, as the relief effect in the labour market is postponed.

Along these lines, the Recommendation 12 of the Toledo Pact proposes to promote the permanence of active workers, so that the real retirement age (above 64 years at the moment) approaches the legal one (66 years in 2021 and 67 years in 2027). In addition, the tightening of early retirement ${ }^{28}$ is yet another reason to try to keep workers in the labour market longer ${ }^{29}$. Parametric changes (retirement age, conditions of access to the

workers from experiencing a drastic reduction in their income after a certain age due to circumstances such as unemployment or the job instability after the age of 50 .

${ }^{25}$ Since 2013, a transitional period was opened until January 1, 2022, in which the contribution period required to calculate the pension will progressively go from 15 years to 25 years, one year each year.

${ }^{26}$ SCHOUKENS, Paul and BARRIO, Alberto, "Platform work in self-employment: new challenges for social protection", Revista del Ministerio de Trabajo, Migraciones y Seguridad Social, 2019, n¹44, pp.5051.

${ }^{27}$ Beneficiaries of contributory pensions of the Social Security system, who do not receive income from work, capital or economic activities and capital gains, in accordance with the concept established by the Personal Income Tax (IRPF), or receiving them, do not exceed the amount established annually by the "Ley de Presupuestos Generales del Estado [General State Budget Law]", will have the right to receive the necessary supplements to achieve the minimum amount of pensions, provided that they reside in Spanish territory, in the terms that are determined by law or regulation (art. 59 LGSS).

${ }^{28}$ In the same recommendation 12 it is stated that early retirement should be "reserved" for workers with long contribution careers, to avoid being used as a way to regulate employment and due to the negative impact caused by the penalty for retiring early (cuts of up to 28\%) and modify them with three criteria: if this retirement is voluntary or forced; if you have been listed for many years; and depending on the sector in which it occurs.

${ }^{29}$ Early retirement at the will of the worker is possible two years before the ordinary retirement age, provided that 35 years of contributions to the Social Security system are credited. Following art. 208.1 c) LGSS, the possibility of an early retirement pension being recognized for workers who decide to retire early 
system) are stronger from a budgetary point of view, but less controversial in political terms and, moreover, they do not interfere on current pensioners, a very cohesive and influential group inside the Spanish electorate.

In addition, the incentives to prolong working life seem to work against platform workers, since they tend to be a group of younger workers. Let us remember that, following Spanish legislation, retirement is a right and not an obligation. "Pacto de Toledo" calls for measures supporting the "voluntary extension" of working life, combining the pension and the income from a professional activity ${ }^{30}$. Although the relationship between the increase in the employment of the elderly and the employment opportunities and wage rates of the young is not clear, there are tremendous imbalances in the employability, job placement and training of young workers in the workplace. For this reason, a trend which has appeared clearly along the economic crises of the last decade is the relative weight loss of young people in the labour market compared to older groups.

What has been discussed in this section leads to a first caution about whether public finances are going to be sustainable in the coming years to maintain the viability and sufficiency of the public pension system. The main causes of the decline in Social Security income derive from the aging of the population, since there are more and more pensioners and fewer contributors; a longer life expectancy of pensioners, who are perceiving their pension for more years; and a higher average pension. The appearance of digital platforms and their new forms of employment will aggravate these previous problems with a growing job precariousness. The important increase of the group of selfemployed persons without employees is a major concern for the European Council, as this group has limited access to affordable social security protection ${ }^{31}$.

We need to face this problem in a moment that our pension system faces an obvious financing and viability problem in the coming years, mainly due to demographic facts. Given the structural weakness of the income from social security contributions, it is reasonable to propose a rebalancing of the financial model. Not all social security models face this threat with the same intensity. The Nordic model and the Beveridge-founded model $^{32}$ suffer it to a lesser extent, because they rely primarily on taxes and not on social

when the amount of this type of pension does not reach the amount of the legal minimum pension that would correspond to the fulfilment of 65-year-old. This requirement is not required when early retirement is associated with a cause beyond the control of the worker, such as a business restructuring, where art. 207 LGSS and the regulation of early retirement for reasons not attributable to the worker (non-voluntary termination of work).

${ }^{30}$ The aim is to reinforce what is known as the active retirement system, established in 2013, which consists of making a percentage of the retirement pension compatible with carrying out any work for other workers (part-time or full-time) or even on their own. The percentage of the retirement pension that is charged for active retirement is $50 \%$ of what corresponds in each particular case. But it is also about promoting delayed retirement, whose supplements $(2 \%, 2.75 \%$ or $4 \%$ ) established by Law 27/2011 have been clearly insufficient to develop it properly. Remember that in the case of delayed retirement, the collection of the pension is not compatible with the performance of any work.

${ }^{31}$ COUNCIL OF THE EUROPEAN UNION, Council Recommendation of 12 July 2016, Official on the 2016 National Reform Programme of the Netherlands, Journal of the European Union, 12 July 2016/ C 299/10, no 2, eur-lex.europa.eu.

32 BEVERIDGE, William, "Social insurance and allied services. 1942", Bulletin of the World Health Organization, vol. 78, $\mathrm{n}^{\circ}$ 6, pp. 847-855. 
contributions. However, the expansion of the subjects that need protection can affect the sustainability of the system, and the universal benefit is minimal, although the role of Social Security is fundamentally to avoid poverty. In our case, that could happen to promote a universal basic income from a certain retirement age with a profound rethinking of the tax system that is already today manifestly unsatisfactory in Spain, including the taxation of companies.

\section{Conclusions}

The globalization and digitization of the economy has led to an increase in the presence of platform companies, facing a very competitive environment. This increased competition requires a greater labour flexibility. For this reason, most of the platform companies use a non-traditional operating model based on hiring self-employed workers, as opposed to the "classic" or "typical" labour relationship including employees with a stable contract. These workers are usually very affected by job instability and by a great variability and uncertainty in their usual income.

This article has analysed the consequences of the greater job instability and lack of protection of this group of digital platforms workers in two areas. In the first part, the article studied the effect on the labour legal framework derived from these new business models. In the second part, the article analysed the effects derived from the growing development of the platform economy for the Spanish Social Security system.

The hiring of self-employed workers by the platforms is very controversial. The doctrine is dominated by two positions: one which defends that all these workers should be considered employees and should remain under the umbrella of the general labour legislation; and another which proposes a legal transformation to make these special workers fit. On the one hand, introducing a special legislation can devaluate the protection of workers if the so-called "uberization" of the economy increases and workers lose their labour rights. But, on the other hand, as the social rights evolve, it is currently convenient to propose measures in favour of a broader and more homogeneous protection that integrates the new atypical forms of work that have appeared with the digital transformation of economy. These new technological companies have a new form of business organization that means that the classic signs of employment have changed, so they must be replaced by new indicators of employment derived from the digitization of the economy.

In legal practice, Spanish courts have recognized the employment status of workers in digital delivery companies. But this recognition only affects one economic sector, and the justice has hardly intervened in the rest of the platform companies. Furthermore, the only legislative reform carried out has also focused exclusively on this delivery sector and has done so very timidly. Therefore, it still does not seem foreseeable that the obligation to establish an employment relationship will be extended to most digital platform companies. However, even if this happened and all platform workers were registered in the General Social Security Scheme, regardless of the length of their working day, it is 
foreseeable that, due to the characteristics of the model, most of these workers will contribute by the interprofessional minimum -the minimum contribution bases are linked by law to the minimum interprofessional salary- as part-time worker. One of the problems that this entails is the difficulty that, for a wage earner with fixed hours, it would suppose the necessary flexibility to adapt to the flexible hours of the home delivery activity. In addition, digital companies will continue to look for loopholes to try to continue having employees who are engaged as freelancers.

The public powers could have opted for regulations that support the digital economy with a greater protection for workers, instead of forcing the firms to hire their employees as paid workers. This has happened in many other European countries, such as France, which have reinforced the basic principles of the European social model to try to solve the vulnerability faced by workers in this sector.

The second part of the article has analyzed the effects derived from the growing development of the platform economy for the Spanish Social Security system. The analysis has focused both on the effects of the protective action of the welfare state for these workers, as well as on its impact on the financing of the public pension system. This system, whose main source of income is social contributions, needs a broad base of contributors compared to the number of pensioners. The system is always based on two great principles of the system, the solidarity and the contributivity. The normative changes of the last years have deepened in the reinforcement of both principles. The principle of solidarity has been implemented in the benefit side, for example, by raising the minimum pensions and limiting the increase of maximum pensions. The contributory principle has been approached from the contribution side, by gradually increasing both the number of years for the calculation of the pension regulatory base and the maximum contribution base.

These changes introduced in the Social Security system in recent years may affect certain groups, and particularly platform workers. The rise of the digital economy may cause the percentage of self-employed workers to rise continuously compared to employees. Many digital platform workers fall under the Special Regime for Self-Employed Workers (RETA). This poses a serious problem of inadequate future benefits for these workers, which results into an insufficient level of protection. Thus, the benefits for workers in the digital economy can be particularly affected. Demanding long professional careers and more years of contributions from workers marked by temporary employment can lead, on the one hand, to an insufficient funding for the system as a whole and, on the other, to an insufficient generation of future individual contributory pension rights. This could lead many of these workers to place themselves on the margins of the system, close to the minimum pensions. Incentives to extend working life also seem to play against platform workers, since they tend to be a group of younger workers. Let us remember that, following Spanish legislation, retirement is a right and not an obligation. Likewise, the lower number of hours worked affects the salary, and will also affect the future retirement pension that will be accessed by these workers. 
Job instability not only negatively affects the workers themselves, but may also hinder the viability and adequacy of the public pension system. The decline in the birth rate, the aging of the population and the decline in income from social contributions due to the new work model of platform companies can put the financial base of Social Security at risk. Social security, especially labour-related social security schemes, reflect past policy designs. So, if we want to provide a proper protection to platform workers, we have to fundamentally rethink the design of labour-related social security schemes, starting from the reality in which these workers perform their jobs, and facing that this is an important issue for many other workers in similar situation, that should compensate the instability of their professional careers and contributions. Only in this way, a significant reduction in the average amount of benefits and retirement pensions could be avoided. An additional emphasis should be placed as well on the financial side, looking for alternative sources of financing.

The previous transformations are causing a change in the income structure of Social Security, which may progressively be based less on the social contributions of workers. Therefore, the income structure of the public pension system must be made more flexible to improve its viability and solvency, not losing sight of the defence of the fundamental social rights of workers.

\section{Bibliography}

BARCELÓ FERNÁNDEZ Jesús, "Cerco a los falsos autónomos en las plataformas digitales" [Siege of false self-employed on digital platforms], Revista General de Derecho del Trabajo y de la Seguridad Social, 2020, nº 57.

BEVERIDGE, William, "Social insurance and allied services. 1942", Bulletin of the World Health Organization, vol. 78, nº 6, pp. 847-855.

GALA DURÁN, Carolina, "El impacto de la robotización y de las plataformas virtuales en los sistemas de seguridad social europeos, en particular el caso de España", [The impact of robotization and virtual platforms on European Social Security systems, in particular the case of Spain] in Digital Work and personal data protection: key issues for the labour of the 21st century, Newcastle, Cambridge Scholars Publishing, 2017.

GIL, Javier, “QQué son las economías colaborativas” [What are the sharing economies?], Revista Papeles de Relaciones Ecosociales y Cambio Global, Spring 2018, n 141. https://www.fuhem.es/media/cdv/file/biblioteca/revista_papeles/141/Que-son-laseconomias-colaborativas-JGil.pdf.

PESOLE, Annarosa, BRANCATI, Cesira Urzi., FERNÁNDEZ-MACÍAS, Enrique, BIAGI, Federico, GONZALEZ VAZQUEZ, Ignacio, Platform workers in Europe, Luxembourg: Publications Office of the European Union, 2018. 
PRIETO PADIN, Patricia, "La calificación jurídica de TRADE en la prestación de servicios a través de las plataformas digitales delivery: una solución contractual y judicial en entredicho" [The legal qualification of TRADE in the provision of services through delivery digital platforms: a contractual and judicial solution in question], Revista General de Derecho del Trabajo y de la Seguridad Social, 2020, nº 56.

RODRIGUEZ FERNÁNDEZ, María Luz, "Protección social para los trabajadores de la economía de plataforma: propuestas para aliviar su vulnerabilidad" [ Social protection for workers in the platform economy: proposals to alleviate their vulnerability], Revista General de Derecho del Trabajo y de la Seguridad Social, n. 57, 2020.

ROJO TORRECILLA, Eduardo, "Pues sí, la saga Glovo (y los glovers) merecen un caso práctico. Notas a la sentencia del TS de 25 de septiembre de 2020, que declara la laboralidad, y recordatorio de las sentencias del JS núm. 39 de Madrid de 3 de septiembre de 2018 y del TSJ de Madrid de 19 de septiembre de 2019 (y II)" [Yes, the Glovo saga (and the glovers) deserve a practical case. Notes to the judgment of the Supreme Court of September 25, 2020, which declares employment, and reminder of the judgments of JS $\mathrm{n}^{\mathrm{o}}$. 39 of Madrid of September 3, 2018 and of the Madrid Supreme Court of September 19, 2019 (and II)], Blog of Eduardo Rojo Torrecilla, October 2, 2020. https://translate.google.com/translate?hl=es\&prev= t\&sl=es\&tl=en\&u=http://www.edu ardorojotorrecilla.es/2020/10/pues-si-la-saga-glovo-y-los-glovers_2.html

SANCHEZ CORUJO, Borja, "La gran transición: la economía de plataformas digitales y su proyección en el ámbito laboral y de la Seguridad Social" [The great transition: the economy of digital platforms and its projection in the workplace and Social Security], Temas Laborales, 2018, $\mathrm{n}^{\circ} 141$.

SCHOUKENS, Paul and BARRIO, Alberto, "The changing concept of work: When does typical work become atypical?”, European Labour Law Journal, 8(4), 2017.

SCHOUKENS, Paul and BARRIO, Alberto, "Platform work in self-employment: new challenges for social protection", Revista del Ministerio de Trabajo, Migraciones y Seguridad Social, 2019, nº144.

SPASOVA, Slavina, BOUGET, Denis, GHAILANI, Dalila and VANHERCKE, Bart, Access to social protection for people working on non-standard contracts and as selfemployed in Europe. A study of national policies, European Social Policy Network (ESPN), European Commission, Brussels, 2017.

TODOLÍ-SIGNES, Adrián, “El impacto de la 'Uber Economy' en las relaciones laborales: los efectos de las plataformas virtuales en el contrato de trabajo" [The impact of the 'Uber Economy' in labour relations: the effects of virtual platforms in the employment contract], IUS Labor, December $\quad 2015, \quad \mathrm{n}^{\circ} \quad 3$. https://translate.google.com/translate?hl=es\&prev= t\&sl=es\&tl=en\&u=https://ssrn.com labstract\%3D2705538

TODOLÍ-SIGNES, Adrián, El trabajo en la era de la economía colaborativa [Work in the collaborative economy era], Tirant lo Blanch, 2017. 
TODOLÍ-SIGNES, Adrián, "Nuevos indicios de laboralidad en la economía de plataformas virtuales (Gig economy)" [New signs of employment in the virtual platform economy (Gig economy)], Papeles de relaciones ecosociales y cambio global 2017/18, $\mathrm{n}^{\mathrm{o}} 140$.

\section{Anexo}

CERIC (Centre for Employment Relations Innovation and Change), The Social Protection of workers in the Platform Economy, European Commission, IP/A/EMPL/2016-11, November 2017. http://www.europarl.europa.eu/supporting$\underline{\text { analyses }}$

COUNCIL OF THE EUROPEAN UNION, Council Recommendation of 12 July 2016, Official on the 2016 National Reform Programme of the Netherlands, Journal of the European Union, 12 July 2016/ C 299/10, nº 2, eur-lex.europa.eu.

ILO (International Labour Organization), Non-standard employment around the world: Understanding challenges, shaping prospects (Full report in English and summary in Spanish entitled "El empleo atípico en el mundo: retos y perspectivas" [Atypical employment in the world: challenges and prospects]), Geneve, 2016. 